ISSN 2078-6441. Вісник Львівського університету. Серія географічна. 2013. Випуск 41. С. 76-82.

Visnyk of the Lviv University. Series Geography. 2013. Issue 41. P. 76-82.

$330.15: 502.35$

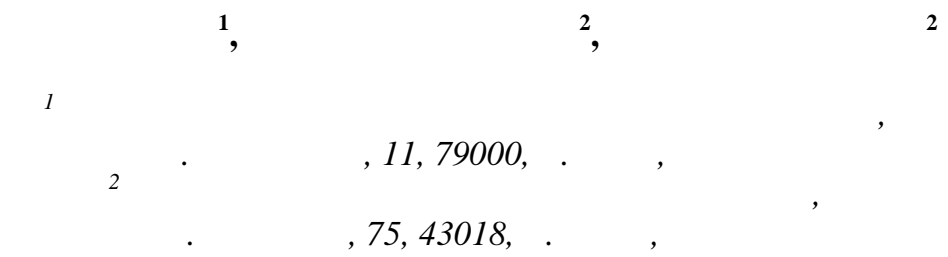

икон но еколого-економічний н ліз чинників впливу н ст н т розвиток туристичних ресурсів, розглянуто підходи вчених до їхньої кл сифік ції, з пропонов но систему з ходів, що можуть сприяти розвитку туризму в меж х досліджув ної території.

лючові слов : туристичні ресурси, р ціон льне використ ння, розвиток туризму, вплив чинників.

уч сний ст н т розвиток туристичних ресурсів більшість дослідників визн ч $є$ як нест більний, нестійкий, нест лий, для якого х р ктерні деструктивність, незл годженість, низьк ефективність, нер ціон льність використ ння н явного туристичного потенці лу, зрост ння нтропогенних н в нт жень, висн ження 6 г тьох видів туристичних ресурсів, збільшення обсягів з бруднення туристичних комплексів, зниження якості середовищ прожив ння н селення.

роблеми р ціон льного використ ння т охорони туристичних ресурсів н були зн чної в ги в н шій кр їні. е зумовлено передусім тим, що протягом б г тьох десятиліть у господ рське життя кр їни було з лучено зн чний потенці л, щор з більше природних ресурсів (землі, води, лісу) потр пляє до виробничого обігу. н кше к жучи, п нув в екстенсивний х р ктер використ ння природних ресурсів, який призвів до суттєвих нег тивних н слідків, пов'яз них з використ нням, дегр д цією т з брудненням земель і водних джерел, не з вжди обгрунтов ним вирубув нням лісів, нер ціон льним використ нням мінер льно-сировинних ресурсів.

т ну т розвитку туристичних ресурсів, функціонув нню туристичних регіонів i чинник м, що вплив ють н них, присвячені пр ці провідних н уковців, зокрем , . орущ к , . еклич, . олошин , . ер симчук, . ринів, . нильчук , . ейлі, . орін, . бушкін, . в рт льного, . отляров, . иф'як, . льської, . ельник, . к ченко, . м ль, . річков , . коли, . м гіної.

ьогодні є кту льними і потребують под льшого вивчення окремі пит ння дослідження чинників впливу н процеси використ ння й охорони туристичних ресурсів.

ході викон ння дослідження пост влено низку з вд нь, с ме:

- про н лізув ти підходи вчених до виявлення основних груп чинників, що вПлив ють н ст н т розвиток туристичних ресурсів;

- $\quad$ вивчити основні види чинників впливу н ст н т розвиток туристичних ресурсів регіонів кр їни;

(C) олошин ., твійчук ., ер симчук ., 2013 
- 3 пропонув ти систему кл сифік ції з зн чених чинників з лежно від специфіки видів туристичних ресурсів регіону.

езв ж ючи н зн чну кількість грунтовних н укових пр ць із з зн ченої проблем тики, у вітчизняній н уковій літер турі ще не приділено дост тньої ув ги спект м p ціон льного використ ння туристичних систем як скл дової орг ніз ції туристичної індустрії. окрем , нем є н укових досліджень з пит нь формув ння екологічно й економічно зб л нсов ної глоб льної т н ціон льної політики використ ння т ких ресурсів.

ільшість дослідників туризму вирізняе дві групи чинників розвитку туристичних ресурсів - соці льно-економічні й природні. меж х соці льно-економічних досліджень, з звич й, розрізняють природні т нтропогенні чинники. ід природними розуміють чинники, що діють нез лежно від людини, без ії уч сті бо пов’яз ні з ії біологічною сутністю. нтропогенними н зив ють будь-які процеси зміни довкілля, зумовлені діяльністю люди. екології прийнято виділяти три групи чинників, які, зокрем , вплив ють н ст н туристичних урбо- т екосистем: біотичні, біотичні й нтропогенні. ричому нтропогенні чинники н ст н т розвиток туристичних ресурсів можуть вплив ти прямо т опосередков но. прикл д, прямий вплив вир ж ється через охорону туристичних ресурсів метод ми з повід ння тощо, непрямий (опосередков ний) вплив виник є вн слідок зміни клім ту, порушень біоценотичних умов існув ння орг нізмів. н шу думку, н йконструктивнішу модель чинників розвитку туризму, отже, і туристичних ресурсів 3 пропонув в московський учений . орін у 70-х рок х

ст. уть моделі зводил сь до поділу чинників н генерув льні, тобто т кі, що сприяють розвитку туристичних ресурсів, i ті, які ре лізують туристичні потреби.

инники, що вплив ють н ст н т розвиток туристичних ресурсів, дослідники кл сифікують відповідно до м сшт бу туристичного ринку, у якому з діяні ці ресурси.

т кій кл сифік ції виділяють три рівні:

- глоб льні, тобто чинники, які діють у міжн родному чи світовому м сшт бі;

- н ціон льні - чинники, які виявляють вплив н рівні держ ви;

- регіон льні - чинники, що вплив ють н ст н т розвиток туристичних ресурсів у меж х окремого регіону [5, с. 83].

к стверджує проф. . кол , н формув ння туристичного ринку регіону, отже, н ст н т розвиток туристичних ресурсів зн чно вплив ють б зові скл дові туристичного продукту: к піт л, технології, к дри. чений з пропонув в т ку кл сифік цію чинників н рівні держ ви: доходи спожив чів, ціни н тов ри т послуги, демогр фічний спект, ступінь мех ніз ції виробництв і спожив ння, рівень урб ніз ції території тощо.

нший дослідник туризму . ифяк, розгляд ючи пит ння орг ніз ції туристичної діяльності в кр їні, т кож н вів перелік чинників, які формують туристичний ринок і вПлив ють н ст н т розвиток туристичних ресурсів, с ме: демогр фічні особливості, м тері льне т соці льне ст новище н селення, рівень освіти гром дян, середня трив лість відпустки в держ ві, професійн з йнятість тощо.

. орущ к про н лізув в проблеми формув ння стр тегії розвитку туристичних регіонів і д в повнішу кл сифік цію чинників впливу н ст н т розвиток туристичних ресурсів. ін стверджув в, що розвиток туризму в регіон х відбув ється повільно порівняно $з$ т ким процесом у світових туристичних регіон х. ослідник виділив т к зв ні чинники, що г льмують ст лий розвиток туризму в регіон х кр їни, отже, не повною мірою сприяють р ціон льному використ нню туристичних ресурсів: недост тній рівень 3 стосув ння н явних туристичних ресурсів, низький рівень розвитку інфр структури; недост тній рівень розвитку з лізничної мережі регіонів. кож втор 
виділив ст тичні й дин мічні чинники, що вплив ють н ст н т розвиток туристичних ресурсів.

о ст тичних дослідник з числив сукупність природно-геогр фічних чинників. они є ст лими. юдин пристосовує їх до туристських потреб, робить доступнішими для використ ння. риродно-клім тичні й геогр фічні чинники регіону виявляються в кр сивій, б г тій природі, клім ті, рельєфі місцевості, підземних б г тств х (мінер льні води, печери тощо). ультурно-історичні чинники (п м'ятки рхітектури, історії) теж вв ж ти ст тичними. тже, с м ст н туристичних ресурсів $є$ чинником впливу н їхній розвиток у м йбутньому.

о дин мічних н леж ть демогр фічні, соці льно-економічні, м тері льно-технічні й політичні чинники. они можуть м ти різну оцінку, зн чення, змінне в ч сі т просторі [3, c. 27].

інною озн кою т кої кл сифік ції є те, що втор виділив чинники, які вр ховують ст н т розвиток не тільки природних, й культурно-історичних туристичних ресурсів, т кож чинники, що г льмують ст лий розвиток туризму, й нег тивно вплив ють н ст н т розвиток туристичних ресурсів, хоч ці чинники не х $\mathrm{p}$ ктеризують, який с ме вплив є н окремі туристичні ресурси, дже ст лий розвиток туризму передб ч є збереження туристичного потенці лу для м йбутніх поколінь.

ході дослідження регіон льної політики розвитку рекре ційної сфери . ер симчук т . лядін уз г льнили підходи до визн чення чинників розвитку рекре ційної сфери т виділили стримув льні й ктивізув льні чинники, розділивши другі н екстенсивні т інтенсивні.

втори стверджують, що економічні чинники розвитку визн ч ють можливості ефективного використ ння ресурсного потенці лу в регіоні з вдяки створенню рекре ційних послуг як в жливої умови зрост ння суспільного добробуту [2, с. 17].

н шу думку, з позиції ст лого розвитку туристичних ресурсів із н ведених кл сифік цій треб виокремити чинники, що х р ктеризують с ме ст лий розвиток. о них н леж ть економічні, соці льні т екологічні чинники. голосимо, що чинники, які вплив ють н ст н і розвиток туристичних ресурсів, не одн кові з змістом, х р ктером т сферою впливу н конкретний туристичний ресурс, рівнем функціонув ння, ч совим критерієм, н прямом т способом впливу. к різном нітність чинників зумовлен , передусім, різнотипністю туристичних ресурсів, дже поняття “туристичні ресурси” охоплює не тільки їхню природну т культурно-історичну групи, й допоміжні т дод ткові ресурси. ому не з вжди виділені чинники одн ково вплив ють н ті чи інші туристичні ресурси. крім того, з зн чимо, що, з огляду н н явні кл сифік ції туристичних ресурсів, чинники, які будуть визн ч льними для розвитку однієї групи ресурсів п сивно вплив тимуть н іншу групу.

ослідження н укової економічної літер тури з пит нь впливу чинників н ст н т розвиток туристичних ресурсів д ло змогу конст тув ти, що більшість дослідників виділяє чинники впливу н природні т культурно-історичні туристичні ресурси, з лиш ючи поз ув гою інші їхні типи. о того ж, більшість підходів до виділення чинників впливу не д ють змоги охопити всю сукупність туристичних ресурсів, системно т комплексно дослідити чинники, дія яких позн ч ється н ст ні т розвитку туристичних ресурсів.

ьогодні нем є єдності в підход х учених щодо оцінки чинників впливу н ст н т розвиток туристичних ресурсів. в ж ємо, що т к ситу ція виникл, оскільки нем консенсу льного тр ктув ння поняття “туристичні ресурси” т, відповідно до їхньої 
типології, розмежув ння ф кторів впливу н їхній ст н і розвиток, тому потрібен дет льніший розгляд т конкретиз ція чинників впливу для з безпечення ст лого розвитку туризму в регіон х.

н шу думку, доцільно розрізняти чинники впливу з лежно від розвитку конкретної групи туристичних ресурсів. озвиток туристичних ресурсів - поняття б г тогр нне й відобр ж є як збільшення їхньої кількості, т к і зміну безлічі їхніх п р метрів. осліджуючи основи теорії стійкого розвитку економіко-екологічних систем, орщук потр ктув в поняття “розвиток" як незворотну, спрямов ну з кономірну зміну м тері льних т іде льних об'єктів, ун слідок чого виник є новий якісний ст н об'єКт - змін його структури і х р ктеру функціонув ння [4, с. 184].

н веденого тр ктув ння виплив є, що до іде льних об'єктів як конкретного виду туристичного ресурсу можн з числити мову, культуру, релігію туристичного регіону.

тже, можн розмежув ти чинники з озн кою змісту впливун ст н т розвиток туристичних ресурсів. окрем , ув ж ємо з доцільне, розділити їх н економічні, соці льні, екологічні т пр вові. кономічні чинники в контексті впливу н туристичні ресурси пов'яз ні з рівнем розвитку, темп ми, м сшт б ми, територі льною структурою економіки т ст ном туристичних орг ніз цій. лежно від економічного розвитку регіону виник тимуть чинники, які сприятимуть бо не сприятимуть розвиткові туристичних ресурсів.

оці льні чинники пов'яз ні з рівнем, якістю т тр диціями життя, потреб, культурною свідомістю н селення: ст влення до туристів, ст влення до екологічної чистоти продуктів, екологічні визн ч ють умови, можливості й ст н туристичних ресурсних комплексів т окремих туристичних об'єктів. н шу думку, екологічні чинники в цьому вип дку визн чені як глоб льними (світовими), т к і регіон льними екологічними особливостями територій. р вові ф ктори відігр ють провідну роль у підвищенні ефективності використ ння т охорони туристичних ресурсів.

огляду н специфіку туристичних ресурсів кцентуємо н явищі сезонності в туризмі, тому чинники впливу доцільно розгляд ти з позицій розвитку в певну пору року.

крім сезонності, н туристичні ресурси, як і н будь-які інші види ресурсів, вплив ють постійні бо періодичні чинники. ому необхідно з періодичністю дії виділити чинники перм нентного т ситу ційного впливу. прикл д, перм нентний вплив м ють постійні екологічні чинники - глоб льні проблеми біосфери (однією з н йв жливіших проблем охорони культурно-історичних туристичних ресурсів є постійне руйнув ння їх кислотними оп д ми). о ситу ційних чинників, як т ких, що повторюються періодично, можн з числити сезонність. лежно від сезону обсяг туристської діяльності може зн чно колив тися. уристичні орг ніз ції й уст нови вжив ють низку 3 ходів, спрямов них н зменшення сезонних сп дів, н прикл д, уведення сезонної диференці ції цін (підвищені ціни в розп л сезону, помірні - для міжсезоння, знижені для несезонного ч су (різниця у т риф х н мешк ння в готелях з лежно від сезону може досяг ти $50 \%$ ), розвиток тих видів туризму, які не з зн ють сезонних колив нь (конгресовий, діловий)).

м сшт бом впливу, н н шу думку, треб виділити ф ктори глоб льного, міжн родного, н ціон льного, регіон льного т лок льного зн чення. кий критерій розподілу д є змогу визн чити територі льні межі впливу чинник , отже, рівень, н якому потрібно вирішув ти пит ння. прикл д, збереження історико-культурного 3 повідник “ офія иївськ” в столиці кр їни потребує вирішення проблеми н н ціон ль- 
ному рівні, поступове зникнення 3 к рти деяких острівних кр їн як туристичних об'єктів через глоб льне потепління потребують вирішення н рівні всього людств .

т н т розвиток туристичних ресурсів, н н ш погляд, т кож доцільно розглянути н прикл ді екзогенних т ендогенних чинників. кзогенні чинники вплив ють н використ ння т охорону туристичних ресурсів через дію демогр фічних, соці льних, фін нсових, економічних, політичних, пр вових змін тощо. емогр фічні т соці льні чинники охоплюють: н селення туристичного регіону з віковими к тегоріями; збільшення кількості жінок, які пр цюють, і зміну доходу н кожну сім'ю; зрост ння пропорції с мотніх людей; тенденції до пізнішого шлюбу й утворення сім'ї; зрост ння кількості бездітних п р у скл ді н селення туристичного регіону; зменшення іммігр ційних обмежень; збільшення спл чених відряджень і гнучкіших гр фіків робочого ч су; вч сний вихід н пенсію, збільшення усвідомлення туристських можливостей.

пл чені відрядження, гнучкі гр фіки робочого ч су ведуть до розширення к нікулярних періодів, змінюють зовнішність ділового туризму, межі сезонності. відси велик трив лість турів, ч ст їхня періодичність. р ктично всі перелічені вище пок зники т к чи ін кше вплив ють н структуру вільного ч су н селення, що позн ч ється н соці льно-демогр фічних умов х розвитку туризму, відт к відбув ється посилення туристичного тиску н ресурси. е потребує дод ткових з ходів охорони туристичних ресурсів.

о зовнішніх чинників, що вплив ють н ст н т розвиток туристичних ресурсів, н лежить т кож економічні й фін нсові, с ме: поліпшення (погіршення) економічної і фін нсової ситу ції, збільшення (зниження) персон льного доходу, висок (низьк ) туристськ ктивність з лежно від виділеної н відпочинок ч стини доходів, зрост ння (зниження) ч стки коштів, що виділяє суспільство н покриття витр т н туризм і подорожі. кож до зовнішніх чинників в рто з числити зміни політичної т пр вової ситу ції в кр їні тощо.

ндогенні чинники - це чинники, що діють безпосередньо в меж х туристичних ресурсів. они визн ч ють їхню н явність вл сне н тій чи іншій території, їхнє геогр фічне положення, клім тичне р йонув ння тощо. ціон льне використ ння й охорон туристичних ресурсів зумовлене в цьому вип дку їхніми кількісними т якісними пок зник ми. о внутрішніх чинників н леж ть процеси попиту і пропозиції конкретних туристичних ресурсів, зрост ння ролі з собів м сової інформ ції т зв'язків з гром дськістю в просув нні, рекл мі й ре ліз ції туристичних продуктів [3].

сі зг д ні чинники м ють різновекторний х р ктер, отже, можуть сприяти бо не сприяти розвитку туристичних ресурсів. ступенем впливун ст н т розвиток туристичних ресурсів розділимо їх н конструктивні т деструктивні. кий поділ ст не фунд ментом розмежув ння змін, що сприяють бо не сприяють р ціон ліз ції використ ння т охорони туристично-ресурсного потенці лу. о конструктивних чинників, що позитивно вплив ють н ст н т розвиток туристичних ресурсів, з числимо, розвинену інфр структурну б зу туризму, р ціон льне використ ння н явних туристичних ресурсів т їхню охорону, підвищення рівня культури туристів, удоскон лення м тері льної б зи н з с д х впров дження досягнень н уково-технічного прогресу, включ ючи використ ння іннов ційних технологій. н чно ширшу структуру м є модель сукупності деструктивних чинників, які нег тивно вплив ють н ст н т розвиток туристичних peсурсів. х, н н ш погляд, треб розподілити н ризикові, з грозливі т небезпечні.

ід ризиковими чинник ми розумітимемо існув ння ймовірності порушення рівнов ги в нег тивний бік у системі туризму - туристичні ресурси, н прикл д, збільшення кількості відвідув чів того чи іншого туристичного об’єКт . кщо порушення рівнов ги вже відбу- 
лося, то треб виділити з грозливі чинники впливу. кі чинники призводять до змін у ст ні туристичних ресурсів, що ст вить під з грозу їхнє збереження для м йбутніх поколінь. ебезпечні чинники зд тні вплив ти не тільки н ст н т розвиток туристичних ресурсів, й н інші ресурси, створюючи небезпеку повного зникнення того чи іншого туристичного ресурсу. о чинників, що нег тивно вплив ють н ст н т розвиток туристичних ресурсів, н леж ть: кризи, зрост ння зовнішньої з боргов ності, політичн нест більність, зрост ння цін н тов ри спожив ння, безробіття, стр йки, криміногенн обст новк , фін нсов нест більність (інфляція, ст гн ція в лют), скорочення обсягів особистого спожив ння, нег р зди з екологічною ситу цією, 6 нкрутство туристських фірм, посилення туристських форм льностей, невикон ння турпідприємств ми своїх зобов'яз нь тощо.

тже, н процеси використ ння й охорону туристичних ресурсів вплив є велик груп чинників, які відрізняються природою т регіон льним поширенням. егіон льні чинники вплив ють через збільшення обсягів м тері льних ресурсів туризму в регіоні, рівень урб ніз ції території, регіон льні особливості, звичок н селення тощо; лок льні- н використ ння т охорону туристичних ресурсів у вигляді будівництв нових об'єктів туризму, форми н д ння т й рівня комфортності житл для туристів, обл дн ння туристичних м йд нчиків з соб ми для сміття, проведення контрольних експертиз туристичних об'єктів тощо.

иділені н ми чинники є всеохопними і зд тні вплив ти н більшість типів туристичних ресурсів. огляду н специфіку туристичних ресурсів н д лі доцільно досліджув ти чинники, які вплив ють н туристичні ресурси, що існують у вигляді об'єктів розміщення туристів - готелів, кемпінгів, турб з тощо; інфр структурних г лузей - шляхи сполучення, торгівля, гром дське х рчув ння, інформ ційно-туристичні центри т ін.; контрольно- дміністр тивні ресурси - прикордонні, міліцейські, митні служби т б г то ін.

\section{СПИСОК ВИКОРИСТАНОЇ ЛІТЕРАТУРИ}

1. олошин . . собливості геохімічного з бруднення при втом гістр льних смуг олині : моногр фія / . . олошин, . . твійчук, . . епкий. - уцьк : ерен, 2009. - 244 c.

2. ер симчук . . егіон льн політик розвитку рекре ційної сфери: мех нізми формув ння т ре ліз ції : моногр фія / . . ер симчук, . . лядін . - уцьк : дстир'я, 2006. - 161 с.

3. орущ $\kappa$. роблеми формув ння стр тегії розвитку туристичних регіонів : моногр фія / . орущ к. - ьвів : кр їни, 2006. - 288 с.

4. орщук . . снови стійкого розвитку еколого-економічних систем : моногр фія / . . орщук. - ьвів : стр-7, 2007. - 436 с.

5. озвиток туристичного бізнесу регіону : моногр фія / [з ред. . . коли]. - ернівці : ниги- , 2007. - 292 с.

6. $\kappa$ ченко . . т лий розвиток туризму: теорія, методологія, ре лії бізнесу : моногр фія / . . к ченко. - 2-ге вид., випр. т доп. - . : иїв. н ц. торг.-екон. ун-т, 2009. -463 c. 


\title{
ECOLOGICAL AND ECONOMIC ANALYSIS OF FACTORS OF INFLUENCE ON STATE AND DEVELOPMENT OF TOURISM RESOURCES
}

\author{
Ivan Voloshyn ${ }^{1}$, Liudmyla Matviychuk ${ }^{2}$, Bozhena Gerasymchuk ${ }^{2}$ \\ ${ }^{I}$ Lviv State University of Physical Education, \\ Kosciuszko St., 11, UA - 79000 Lviv, Ukraine \\ ${ }^{2}$ Lutsk National Technical University, \\ Lvivska St., 75, UA - 43018 Lutsk, Ukraine
}

The publication conducted ecological and economic analysis of factors affecting the status and development of tourist resources, scientists examined the approaches to their classification, proposed a system of measures that can contribute to tourism development within the study area.

Key words: tourism resources, rational use and development of tourism, impact factors.

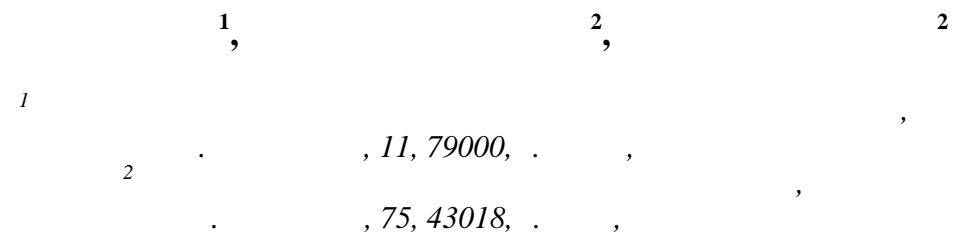

ыполнено эколого-экономический н лиз ф кторов влияния н состояние и р звитие туристических ресурсов, р ссмотрено подходы ученых к их кл ссифик ции, предложено систему мер, которые могут способствов ть р звитию туризм в р мк х исследуемой территории.

лючевые слов : туристические ресурсы, р цион льное использов ние, р звитие туризм , влияние ф кторов. 